\title{
The Effect of Early or Late Breeding on Milk Production in High Producing Lactating Dairy Cows
}

\author{
Gülnaz Yılmazbaş-Mecitoğlu $\mathbf{u}^{1, *}$ \\ ${ }^{1}$ Department of Obstetrics and Gynecology, Faculty of Veterinary Medicine, Uludag University, Bursa, Türkiye \\ *Corresponding Author
}

\section{Article History}

Received: 03 September 2021

Accepted: 17 December 2021

First Online: 01 March 2022

\section{Corresponding Author* \\ Tel.: +902242940827 \\ E-mail: gulnazy@uludag.edu.tr}

\section{Keywords}

Breeding time

Lactation

Milk yield

Dairy cow

\begin{abstract}
The objective of this study was to compare the effect of early or late breeding on milk production in high producing dairy cows. In this aim, the cows with previous average peak milk yield above $45 \mathrm{~kg} / \mathrm{d}(\mathrm{n}=48)$ were divided into two groups; Group1 (early bred) included the cows ( $n=21$ ) were inseminated between 45 to 75 days in milk (DIM) and Group2 ( $n=27$; late bred) were inseminated between 76 to 124 DIM. The cows that became pregnant at their first insemination following first estrus selected for the study. Milk yield was recorded every 5 days after calving for the first 45 days then continued for every 15 days for every each cow. Average DIM in early and late bred cows at insemination were $66(\min , 45 ; \max , 75)$ and $99(\min , 76 ; \max , 124)$, respectively. Average milk yield up to $271 \mathrm{~d}$ was similar between groups, however, average milk yield from 227 to $271 \mathrm{~d}$ was lower $(P<0.04)$ in early bred cows with $26.7 \mathrm{~kg} / \mathrm{d}$ compare to late bred cows with $30.3 \mathrm{~kg} / \mathrm{d}$. Even, there was no relationship between average milk yield up to $271 \mathrm{~d}$, peak milk yield and day of insemination, it may be concluded that milk yield continues with more pronounced stability through the end of lactation in late bred high yielding cows.
\end{abstract}

\section{Introduction}

Optimum herd profitability can be only acquired if it is possible to maintain the balance between milk production and reproduction. The common opinion about maintaining the herd pofitability at optimum level, it is need to be aimed that $12-13$ months calving interval which included one calf per cow in a yearling period. However, according to this strategy the inseminations of dairy cows, especially with high milk yield $(10000-14000 \mathrm{~kg} / 305 \mathrm{~d})$, are coincide with the highest point of lactation when the negative energy balance is most pronounced, and resulted with lower pregnancy rates (Wathes et al., 2007). An also, delaying the first inseminations in lactating dairy cows with high milk production may be more beneficial with getting higher pregnancy rates, reduce the frequency per annual cow of the welfare issues associated with calving and durability of lactations (Sehested et al., 2019). The previous studies reported that conflicting results pointed out that either early pregnancy favorably (Harrison et al., 1974; Funk et al., 1987;
Weller and Foman, 1990; Genizi et al., 1992; Rehn et al., 2000; Arbel et al., 2001) or adversely (Bar-Anan et al., 1979; Weller et al., 1985; Bertilsson et al., 1997; Österman and Bertilsson, 2003) or no effect (Schneider et al., 1981; Jensen et al., 1997; Lehmann et al., 2016; Niozas et al., 2019) on milk production or herd profitability. Recently, the cows are producing much more milk than the cows in most of these earlier studies due to genetic and management improvements (Niozas et al., 2019). Thus, the effects of the time of pregnancy on milk yield still maintain its originality in high yielding dairy cows. The objective of presented study was to compare the milk yield of the cows that became pregnant following their first insemination which between 45 to 75 days (early breeding) or 76 to 124 days (late breeding) postpartum.

\section{Materials and Methods}

Selection criteria for the cows that were included in the study ( $n=48$ ) were 1 ) to be in the second lactation and with a peak of $\geq 45 \mathrm{~kg}$ in the previous lactation 2) to 
have calving without intervention, 3) to become pregnant after insemination in their first heat 4) not to have infectious and metabolic diseases postpartum and 4) to continue their pregnancy throughout the study. Group 1 (early bred), included the cows $(n=21)$ were inseminated between 45 to 75 days in milk (DIM) and Group 2 included the cows ( $n=27$; late bred) were inseminated between 76 to 124 DIM. All cows were in the same commercial dairy herd (approximately 1000 lactating dairy cows) in the South Marmara region, Bursa, Türkiye. Breeding of cows were initiated after voluntary waiting period which is 45 DIM, with artificial insemination followed by estrus detection which was recorded combination with pedometer and visual observations as a reproductive management routine of the farm. Pregnancy examinations were routinely performed on 30, 60 days following insemination and before drying off as part of farm reproductive management procedures. The cows were fed twice daily with a high energy lactating dairy cow ration fed as a Total Mixed Ration (TMR) following National Research Council recommendations (Table 1 ).

Table 1. Feed ingredients for total mixed ration for high producing lactating dairy cow in the study.

\begin{tabular}{|c|c|}
\hline Ingredient & Amount \% of DM \\
\hline Corn silage (32\% DM) & 31.18 \\
\hline Alfaalfa hay (16\% Protein) & 11.61 \\
\hline Wheat straw & 1.85 \\
\hline Triticale silage (34\% DM) & 5.12 \\
\hline Wet orange pulp & 3.93 \\
\hline Wet corn gluten feed (42\% DM) & 9.35 \\
\hline Sodium bicarbonate & 0.64 \\
\hline Toxin binder & 0.04 \\
\hline Yeast (Saccharomyces cerevisiae) & 0.02 \\
\hline Magnesium oxide & 0.20 \\
\hline Dry corn gluten feed & 0.54 \\
\hline Corn gluten (65\% Protein) & 0.79 \\
\hline Hydrogenised rumen bypass fat & 1.57 \\
\hline Dairy Min/Vit complex & 0.04 \\
\hline Cotton seed meal (38\% Protein) & 8.32 \\
\hline Crushed corn grain & 2.29 \\
\hline DDGS & 5.45 \\
\hline Soy bean meal (48\% Protein) & 1.90 \\
\hline Barley & 1.16 \\
\hline Corn & 0.63 \\
\hline Sunflower seed meal (38\% Protein) & 1.00 \\
\hline Molasses (sugar beat) & 0.84 \\
\hline Calcium carbonate & 0.48 \\
\hline Salt & 0.32 \\
\hline Bakery byproducts & 4.43 \\
\hline Wheat middlings & 6.31 \\
\hline
\end{tabular}

Milk yield was recorded every 5 days after calving for the first 45 days then every 15 days for each cow until 271 days; since the last day for which data was not missing in all animals was day 271 in this study. During the time of data collection, the cows that had a disease, including clinical mastitis, that required their referral to the infirmary, were excluded from the study. Data were analyzed using by the computational software of SAS (release 9.2, SAS Institue Inc. Cary, NC). The PROC GLM procedure was performed to compare timing of $\mathrm{Al}$, timing of peak milk, and average peak milk yields associated with different time periods of lactation between groups. Average milk yields $(\mathrm{kg} / \mathrm{d})$ were determined by taking the averages of the milk data obtained for each cow between the groups. The total milk yield (kg) was calculated by multiplying the average 
of the milk yield data obtained for each cow by the time the data covers. The differences with $P<0.05$ were considered significant.

The data evaluated in this study were obtained with the consent of the company where the study was conducted, and no ethics committee decision was required.

\section{Results and Discussion}

F Average days to Al were $66.2 \pm 1.9$ days in the Group 1 and $99.2 \pm 2.6$ days in the Group 2. Average days to peak milk yield was found similar between the groups
$(41.7 \pm 2.1$ days in the Group 1 and $47.3 \pm 2.7$ days in the Group 2). Peak milk yield, milk yield for the first 3 months of lactation, and average milk yield up to $271 \mathrm{~d}$ were similar between the groups (Table 2).

There was no relationship between average milk yield up to $271 \mathrm{~d}$ after calving and postpartum days of insemination (Figure 1). However, average milk yield from 227 to 271 days postpartum was lower $(P<0.04)$ in the early bred cows compare to the late bred cows. (Table 2). Total milk yield from 227 to $271 \mathrm{~d}$ was also different $(P<0.03)$ between the groups $(1135.0 \pm 54.1$ $\mathrm{kg}$ in Group 1; $1308.75 \pm 65.0 \mathrm{~kg}$ in the Group 2, Figure 2).

Table 2. The variables of average milk yield $(\mathrm{kg} / \mathrm{d})$ between the early bred cows inseminated at 45 to $75 \mathrm{DIM}$ or late bred cows inseminated at 76 to 124 DIM.

\begin{tabular}{|c|c|c|c|}
\hline Milk Yield Variables $(\mathrm{kg} / \mathrm{d})$ & $\begin{array}{l}\text { Early bred } \\
\qquad(\mathrm{n}=\mathbf{2 1})\end{array}$ & $\begin{array}{l}\text { Late bred } \\
\qquad(\mathrm{n}=27)\end{array}$ & P value \\
\hline Peak milk yield & $48.1 \pm 0.8$ & $48.4 \pm 1.3$ & 0.92 \\
\hline $\begin{array}{l}\text { Average milk yield at the beginning of } \\
\text { lactation (up to } 91 \mathrm{~d} \text { ) }\end{array}$ & $42.4 \pm 1.2$ & $42.6 \pm 1.1$ & 0.77 \\
\hline $\begin{array}{l}\text { Average milk yield at mid term } \\
\text { lactation (from } 92 \text { to } 226 \text { d) }\end{array}$ & $36.3 \pm 0.9$ & $37.4 \pm 1.4$ & 0.55 \\
\hline $\begin{array}{l}\text { Average milk yield at the end of } \\
\text { lactation (from } 227 \text { to } 271 \text { d) }\end{array}$ & $26.7 \pm 1.0$ & $30.3 \pm 1.3$ & 0.04 \\
\hline Average milk yield up to $271 \mathrm{~d}$ & $38.2 \pm 1.4$ & $39.0 \pm 1.2$ & 0.46 \\
\hline
\end{tabular}

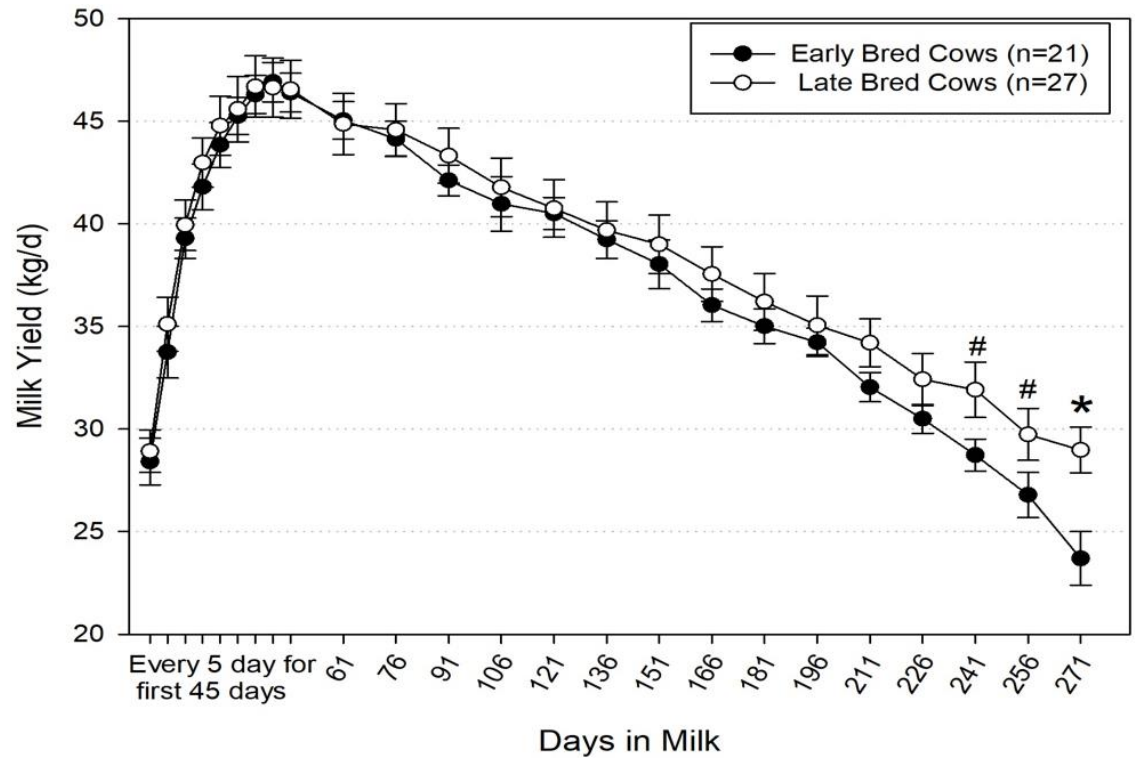

Figure 1. The effect of early or late breeding on milk yield in lactating dairy cows. In this graph, the \# symbol indicates statistical tendency at the level of $P=0.07$ and the symbol * indicate statistical differences at the level of $P=0.007$. 


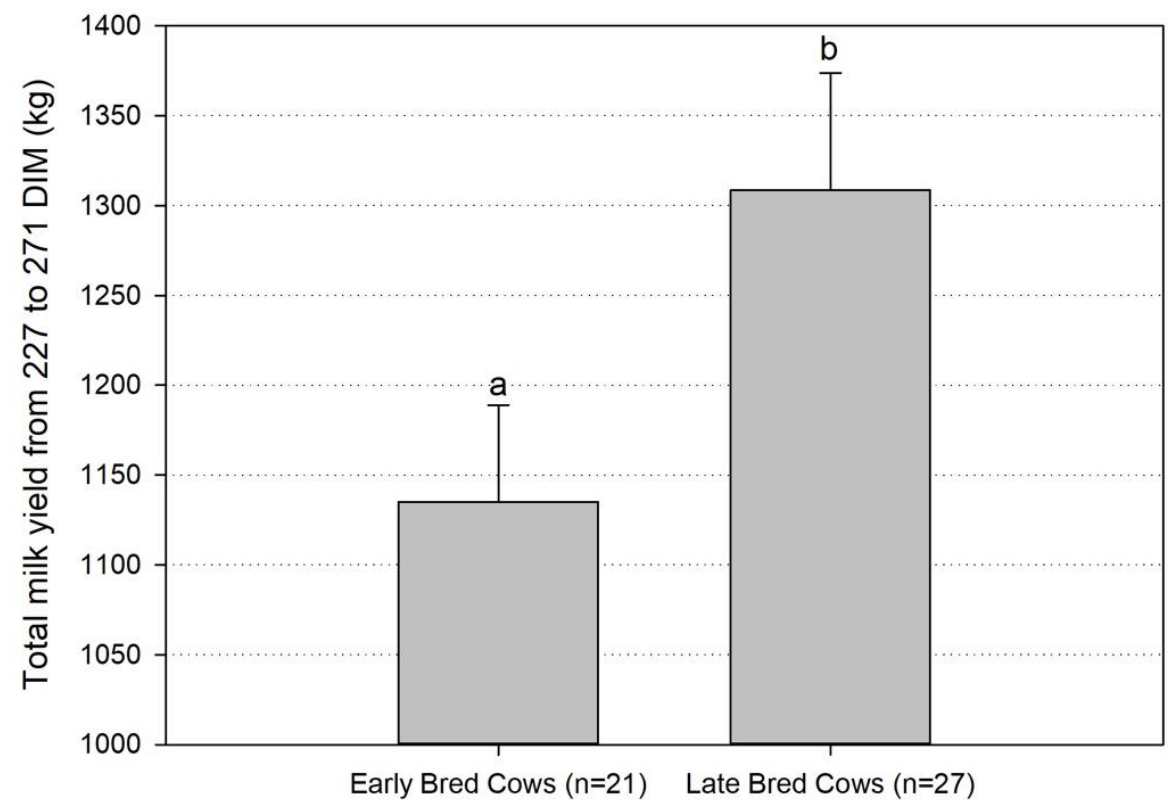

Figure 2. The total milk yield between 227 to 271 days $(\mathrm{kg})$ of lactation in early or late bred cows. In this graph, the a,b symbols indicate statistical difference at the level of $P=0.03$.

Milk production and reproduction are two important factors with respect to profitability of dairy farms and much attention has been given to fertility parameters and their association with milk production. Since insemination time coincide with the period of negative energy balance is most pronounced in high producing dairy cows, delaying the first inserminations in these cows may be more beneficial with both getting higher pregnancy rates and persistency of lactation curve. Intentionally delaying of insemination or voluntary waiting period is termed as extended lactation strategy or extended calving interval in the current literature (Lehmann et al., 2016; Sehested et al., 2019; Burgers et al., 2021a; 2021b). Within the scope of this strategy, it is reported that it may be advantageous for cows to become pregnant when they are in a stage of more positive energy balance and also be dried off at a lower milk yield comparing with in the traditional lactation period (Sehested et al., 2019). In presented study, the milk yield data belongs to the cows that became pregnant following first insemination, was used deliberately; thus, the cows were included in the study went spontaneously through an extended lactation strategy on purpose not because of reproductive failure and their milk yield parameters were able to be evaluated in more physiological conditions.

Some of the previous studies (Bar-Anan et al., 1979; Weller et al., 1985; Bertilsson et al., 1997; Österman and Bertilsson, 2003) reported that longer calving interval which means later pregnancy affects favorably on milk production with producing $29 \%$ more ECM (Bertilsson et al., 1997) and higher milk production per day from one calving to another (Österman and Bertilsson, 2003), some of the studies (Harrison et al., 1974; Funk et al., 1987; Weller and Foman, 1990; Genizi et al., 1992; Rehn et al., 2000; Arbel et al., 2001) reported that early pregnancy affects favorably on milk production. Interestingly, the study included only swedish cows reported that late bred cows resulted with having 5560 days longer duration of lactation, had slightly lower milk yield compare to the early bred cows with shorter duration of lactation. And also it is noted that the late bred cows maintain their lactation however produce less milk (Rehn et al., 2000). Milk production data of the high producing lactating dairy cows in presented study including both milk yield for first 3 months ( $42 \mathrm{~kg}$ ) or for whole lactation period ( $270 \mathrm{~d}, \sim 38.5 \mathrm{~kg}$ ) was not affected by early or late breeding of the cows, similar with the earlier studies (Schneider et al., 1981; Jensen et al., 1997) and the mostly recent studies reported that early or late pregnancy had no effect on milk production even evaluated as Energy Corrected Milk (ECM) production (Niozas et al., 2019) in both primiparous and multiparous cows (Lehmann et al., 2016).

The lower milk yield through the end of lactation in early bred cows in presented study was found to be consistent with the current study (Burgers et al., 2021a) reported that the cows had calving to first service interval is more than $140 \mathrm{~d}$ resulted in better lactation yield, when high-producing dairy cows were selected, as presented in our study. The decrease in milk yield of early inseminated animals in presented study may also be due to the fact that these animals entered the last trimester of their pregnancy compared to the animals in the other group, since the previous reports (Olori et 
al., 1997; Brotherstone et al., 2004) reported that milk yield is negatively affected by pregnancy, especially for the last trimester possibly due to pregnancy associated mammary gland regression and competition for nutrients from the developing fetus (Erb et al., 1952).

In scope of high producing dairy cows, it is reported that both peak milk yield and DIM at peak yield had an effect on the individual cow to maintain a high daily milk yield during extended lactation (Sehested et al., 2019). Average DIM at peak yield was 42 and 47 days in presented study and both were earlier comparing to the recent study (Lehmann et al., 2017) reported that in the multiparous cows managed with longer or shorter lactations, DIM at peak yield were 53 and 59 days and average peak milk yields were 42.7 and 32.5 $\mathrm{kg}$ (of ECM/d), respectively. Although there were no differences between the early (average 66d) or late bred (average 99d) cows in terms of average peak milk yield $(48 \mathrm{~kg} / \mathrm{d})$ in presented study, Burgers et al., (2021a) reported that in the cows that early bred $(<84 \mathrm{~d})$ in their study had lower peak milk yield (40 kg of Fat Protein Corrected Milk, FPCM/d) compare to later bred cows ( $43 \mathrm{~kg}$ of FPCM/d). Even, it is not appropriate to interpret our study and the recent studies (Lehmann et al., 2017; Burgers et al., 2021a) together because the calculation method of peak milk yield in these studies are different, it can be said that the peak milk yield values in our study are higher than the values in these studies when general average constitutes of fat (3-4\%) and protein (3.5\%) in milk are placed in the corresponding places in the ECM (Sjaunja et al., 1991) or FPCM (CVB, 2012) formulas. Earlier DIM at peak yield and higher milk yields in presented study can be explained by the fact that presented study included high milk yielding cows but not performed in a herd basis.

\section{Conclusion}

Average milk yield up to $271 \mathrm{~d}$ of lactation, peak milk yield, and DIM at peak milk yield were not affected by early (average 66 DIM) or late (average 99 DIM) breeding where was more than 30 days between breedings in this study. However, it may be concluded that milk yield continues with more pronounced stability through the end of lactation in late bred cows. Thus, late insemination may contribute to the profitability obtained from milk, especially in the case of high milk yielding cows. Further trials are needed to evaluate the repeatability of this response and evaluation of early or late breeding on persistency and productivity of lactation, should be done not only with milk yield or duration of lactation, but also ECM or FPCM yield, fertility, postpartum health and feeding costs during the this period in the point of herd profitability.

\section{References}

Arbel, R., Bigun, Y., Esra, E., Sturman, H., Hojman, D. (2001). The effect of extended calving intervals in high lactating cows on milk production and profitability. Journal of Dairy Science, 84, 600-608. https://doi.org/10.3168/jdsS0022-0302(01)74513-4

Bar-Anan, R., Soller, M. (1979). The effect of days open on milk yield and on breeding policy post partum. Animal Production, 29(1), 109-119. https://doi.org/ 10.1017/ S0003356100012204

Bertilsson, J., Berglund, B., Ratnayake, G., SvennerstenSjaunja, K., Wiktorsson, H. (1997). Optimising lactation cycles for the high yielding cow. A European perspective. Livestock Production Science, 50, 5-13. https://doi.org/10.1016/S03016226(97)00068-7

Brotherstone, S., Thompson, R., White, I.M.S. (2004). Effects of pregnancy on daily milk yield of Holstein-Friesian dairy cattle. Livestock Production Science, 87, 265269.

https://doi.org/10.1016/j.livprodsci.2003.07.014

Burgers, E.E.A., Kok, A., Goselink, M.A., Hogeveen, H., Kemp, B., Van Knegsel, A.T.M. (2021a). Fertility and milk production on commercial dairy farms with customized lactation lengths. Journal of Dairy Science, 104, 443-458. https://doi.org/10.3168/jds. 2019-17947

Burgers, E.E.A., Kok, A., Goselink, M.A., Hogeveen, H., Kemp, B., Van Knegsel, A.T.M. (2021b). Effects of extended voluntary waiting period from calving until first insemination on body condition, milk yield, and lactation persistency. Journal of Dairy Science, 104, 8009-8022. https://doi.org/10.3168/jds.2020-1991 4

CVB. (2012). Cvb tabellenboek veevoeding (feedstuff table 2012), Centraal Veevoeder Bureau Lelystad, the Netherlands.

Erb, R.E., Goodwin, M.M, Morrison, R.A., Shaw, A.O. (1952). Lactation studies: 1. Effect of gestation. Journal of Dairy Science, 35, 224-233. https://doi.org/10.3168/ jds.S0022-0302(52)93695-3

Funk, D.A., Freeman, A.E., Berger, P.J. (1987). Effects of previous days open, previous days dry, and present days open on lactation yield. Journal of Dairy Science, 70, 2366-2373. https://doi.org/10.3168/j ds.S0022-0302 (87)80297-7

Genizi, A., Schindler, H., Amir, S., Eger, S., Zarchi, M., Foote, R.H. (1992). A simulation study of the effects of the calving interval on milk yields of dairy cows in fixed time periods. Animal Production, 55, 309-314. https:// doi.org/10.1017/S0003356100020997

Harrison, D.S., Meadows, C.E., Boyd, L.J. (1974). Effects on interval to first service on reproduction, lactation and culling in dairy cows. Journal of Dairy Science, 57, 628 (Abstr.).

Jensen, E.L., Wieckert, D.A. Baumann, L.E. (1997). Optimum calving intervals for high producing cows. Journal of Dairy Science, 80 (Suppl. 1), 200 (Abstr.).

Lehmann, J.O., Fadel, J.G., Mogensen, L., Kristensen, T., Gaillard, C., Kebreab, E. (2016). Effect of calving interval and parity on milk yield per feeding day in Danish commercial dairy herds. Journal of Dairy 
Science, 99, 621-633. http://dx.doi.org/10.3168/jds. 2015-9583

Lehmann, J.O., Mogensen, L., Kristensen, T. (2017). Early lactation production, health, and welfare characteristics of cows selected for extended lactation. Journal of Dairy Science, 100, 1487-1501. https://doi.org/ 10.3168/jds.2016-11162

Niozas, G., Tsousis, G., Malesios, C., Steinhöfel, I., Boscos, C., Bolwein, H., Kaskee, M. (2019). Extended lactation in high-yielding dairy cows. II. Effect on milk production, udder health, and body measurements. Journal of Dairy Science, 102, 811-823. https://doi.org/10.3168/jds.2018-15117

Olori, V.E., Brotherstone, S., Hill, W.G., McGuirk, B.J. (1997). Effect of gestation stage on milk yield and composition in Holstein Friesian dairy cattle. Livestock Production Science, 52, 167-176. https://doi.org/10.1016/ S0301-6226(97)00126-7

Österman, S., and Bertilsson, J. (2003). Extended calving interval in combination with milking two or three times per day: Effects on milk production and milk composition. Livestock Production Science, 82, 139149. https://doi.org/10.1016/S0301-6226(03)0003 6-8

Rehn, H., Berglund, B., Emanuelson, U., Tengroth, G., Philipsson, J. (2000). Milk production in swedish dairy cows managed for calving intervals of 12 and 15 months. Acta Agriculturae Scandinavica A Animal Science, 50(4), 263-271. https://doi.org/ 10.1080/090647000750069458

Schneider, F., Shelford, J.A., Peterson, R.G., Fisher, J. (1981). Effects of early and late breeding of dairy cows on reproduction and production in current and subsequent lactation. Journal of Dairy Science, 64, 1996-2002. https://doi.org/10.3168/jds.S0022-0302 (81)82802-0

Sehested, J., Gaillard, C., Lehmann, J.O., Maciel, G.M., Vestergaard, M, Weisbjerg, M.R., Mogensen, L., Larsen, LB, Poulsen N.A., Kristensen, T. (2019). Review: extended lactation in dairy cattle. Animals, 13(suppl1), 65-74.https://doi.org/10.1017/ S175173 1119000806

Sjaunja, L.O., Baevre, L., Junkkarinene, L., Pedersen, J., Setala, J. (1991). A Nordic proposal for an energy corrected milk (ECM) formula. P. Gaillon, Y. Chabert (Eds.), Performance Recording of Animals: State of the Art, 1990, Centre for Agricultural Publishing and Documentation (PUDOC), Wageningen, the Netherlands, pp. 156-157.

Wathes, D.C., Fenwick, M., Cheng, Z., Bourne, N., Llewellyn, S., Morris, D.G., Kenny, D., Murphy, J., Fitzpatrick, R. (2007). Influence of negative energy balance on cyclicity and fertility in the high producing dairy cow. Theriogenology, 68 (Suppl. 1), 232-241. https://doi. org/10.1016/j.therio- genology.2007.04.006

Weller, J.I., Bar-Anan, R., Osterkorn, K. (1985). Effects of days open on annualized milk yields in current and following lactations. Journal of Dairy Science, 68, 1241-1249. https://doi.org/10.3168/jds.s0022-0302 (85)80952-8

Weller, J.I. and Folman, Y. (1990). Effects of calf value and reproductive management on optimum days to first breeding. Journal of Dairy Science, 73, 1318-1326. https://doi.org/ 10.3168/jdsS0022-0302(90)78798-X 